\title{
A review on the detoxification of organophosphorus compounds by microorganisms
}

\author{
Yongliang Zheng, Lifang Long, Yuanyuan Fan, Jianping Gan, Jianping Fang and Weibin Jin*
}

Hubei Key Laboratory of Economic Forest Germplasm Improvement and Resources Comprehensive Utilization, Huanggang Normal University,No.146 Xingang II Road, Huangzhou, 438000, Hubei Province, China.

Accepted 3 May, 2013

\begin{abstract}
Organophosphorus compounds (OPs) are widely used as pesticides and chemical warfare agents (CWAs). These synthetic compounds reside in the environment and cause serious pollution problems. Organophosphorus compounds can be detoxified rapidly by hydrolysis on exposure to environment, which are liable to be influenced by abiotic and biotic factors. Microorganisms isolated from different niches are the predominant entities in the biosphere with an exceptional ability to metabolize various OPs for their growth. The focus of this work is organophosphorus hydrolase (OPH, E.C. 8.1.3.1), which catalyzes the hydrolysis of many organophosphorus compounds and greatly reduces the toxicity and even can completely mineralize them. Several OPH enzymes, including o-phenylenediamine dihydrochloride (OPD), methyl parathion hydrolase (MPH) mevalonate pyrophosphate decarboxylase (MPD) etc, have been identified which accomplish hydrolysis for specific classes of organophosphorus compounds. The functional gene encoding OPH protein have been cloned, expressed and purified in both prokaryotic and eukaryocyte expression vector. To increase the enzyme activity or enhance their broad-spectrum property, the wild activated OPH was used to modify activated sites by the chemical modification of specific amino acid residues with the use of appropriately designed coenzyme analogs. The applications of the functional strains and OPH enzymes in bioremediation of OPs pollutants included: (i) Bioremediation: the technologies can be generally classified as in situ or ex situ; (ii) immobilization: an immobilized enzyme is the OPH that is attached to an inert, insoluble material such as calcium alginate and agar; immobilized whole cell, the target cell is the functional strains that is capable of degrading special OPs; (iii) construction of genetically engineering bacteria. A versatile genetically engineering bacterium that gained more functional genes from different sources was constructed by gene engineering and enzyme engineering, showing a creative and promising application in OPs detoxification.
\end{abstract}

Key words: Organophosphorus compounds, biodegradation, bioremediation, oph, genetically engineering bacteria.

\section{INTRODUCTION}

Organophosphorus compounds (OPs) are most widely used around the world and have been used as pesticides and chemical warfare agents in agriculture and other fields. OPs have the general structure with a terminal oxygen atom (or sulphur atom) connected to phos- phorus by a double bond, that is a phosphoryl group, and two lipophilic groups as well as a leaving group bonded to the phosphorus (Figure 1). Usually, R1 and R2 are aryl or alkyl groups that are bonded to the phosphorus atom either directly (forming phosphinates), or through an oxy- 


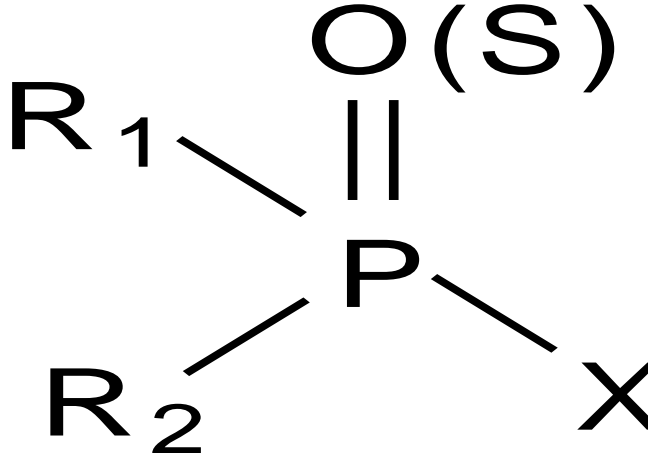

Figure 1. General chemical structure of an organophosphorus compounds.

gen or sulphur atom (forming phosphates or phosphorthioates). The $X$ group, also binding to the phosphorus atom through an oxygen or sulphur atom is called 'leaving group'.

Although OPs play important roles in protecting agricultural crops from insect pests and weeds, and in controlling disease-transmitting vectors, they cause serious environmental pollution problems (Musa et al., 2011). Organophosphorus pesticides (as well as sarin and VX nerve agent) irreversibly inactivate acetylcholinesterase (AChE), which is essential to nerve function in insects, humans, and many other animals. Inhibition of acetylcholinesterase results in an accumulation of the neurotransmitter acetylcholine and the continued stimulation of acetylcholine receptors, and they could case acute or chronic poisoning in human and harm to our health (Ragnarsdottir, 2000).

Organophosphorus compounds can be detoxilized rapidly by hydrolysis on exposure to environment, such as sunlight, air, and soil, although small amounts can be detected in drinking water and food (Musa et al., 2011). Enzymatic hydrolysis of OPs can greatly reduce the toxicity and even completely mineralize them (Hsu et al., 2008; Harper et al., 2006). Various microorganisms capable of biodegrading OPs have been isolated from pollution environment, which is able to use OPs as the sole of carbon, nitrogen or energy source. The most widely characterized phosphotriesterase is the bacterial organophosphorus hydrolase (OPH, E.C.8.1.3.1), which had been isolated from Pseudomonas putida, Flavobacterium, Arthrobacter, etc. It is one of the most crucial enzymes in the detoxification of organophosphorus compounds, such as paraoxon, parathion, methyl parathion, coumphos and diazion. Organophosphorus hydrolase gene (oph, mpd and opd, etc,) were cloned, expressed and purified (Harper et al., 2006; Somara et al., 2002; Gao et al., 2002). Engineered microorganisms, with high efficiency, broad-spectrum substrates and more safe, were constructed in an attempt to completely detoxify OPs.

In this review, the main enzymes properties of organo- phosphorus biodegradation were summarized and the genetically modified and application prospects are put into a perspective involved in organophosphorus hydrolase.

\section{MICROORGANISMS CAPABLE OF DEGRADING OPS}

Although incineration and chemical hydrolysis have been widely used to destroy organophosphorus compounds (Lamoreaux et al., 1997), microorganisms are the predominant entities in the biosphere with an exceptional ability to exploit various OPs for their growth. Therefore, biodegradation is considered to be a reliable costeffective technique and less secondary pollutants for pesticides abatement and a major factor determining the fate of organophosphorus pesticides in the environment. During the last few decades, much research has resulted in isolation and character of microorganisms capable of degrading kinds of OPs. Though these OPs are relatively alien for the microbes, they have evolved novel degradation enzyme and pathway(s) for their metabolism. However, development of these novel enzyme and pathway(s) in the evolutionary time scale is an extremely slow process. They are empowered to inhabit various ecological niches and pursue unusual metabolic and physiological activities (Timmis et al., 1994). OPs were used in their growth as the sole carbon, nitrogen, phosphorus and (or) energy source (Mattozzi et al., 2006; Liu et al., 2004; Bhushan et al., 2000). These microorganisms included bacteria, fungi and algae. Table 1 summarizes the performance of various microorganisms capable of detoxifying OPs.

\section{Organophosphorus hydrolase (oph )}

A variety of microorganisms can detoxify organophosphorus compounds by hydrolyzing them using organophosphorus acid anhydrases (Table 1). These OPsdegrading microbes have been isolated from environment polluted by some organophosphorus compounds for a long period (Allard and Neilson, 1997). They commonly initiate organophosphorus compounds degradation with special functional enzyme by cleaving P-O or P-S bond reaction, and these enzymes have a broad substrate range with a close similarity structure or a chemical functional group, and can hydrolyze a number of organophosphorus compounds. While one of these enzymes or some variant can allow the initial detoxification of an organophosphorus contaminant, the organism may not degrade the hydrolysis products, some of which are toxic and inhibit bacterial growth (Hong et al., 2001; Walker and Keasling, 2002). The OPs are mainly detoxified through oxidation and hydrolysis. Organophosphorus hydrolase (OPH, EC8.1.3.1) is a bacterial enzyme that has been shown to degrade a wide range of organophosphorus pesticides and nerve agents (Sogorb and 
Table 1. Microorganisms capable of detoxifying Organophosphorus compounds.

\begin{tabular}{|c|c|c|c|}
\hline Microorganism & $\begin{array}{l}\text { Organophosphorus } \\
\text { compound }\end{array}$ & Function & Reference \\
\hline \multicolumn{4}{|l|}{ Bacteria } \\
\hline $\begin{array}{l}\text { Flavobacterium sp. } \\
\text { ATCC27551 }\end{array}$ & Parathion, Diazinon & $\begin{array}{l}\text { Decomposed diazinon as sole carbon source and } \\
\text { hydrolyzed to } 2 \text {-isopropyl-6-methyl -4-hydroxy-pyrimidine } \\
\text { and then converted to carbon dioxide }\end{array}$ & $\begin{array}{l}\text { Sethunatha and } \\
\text { Yoshida, 1973; } \\
\text { Kawahara et al., } 2010\end{array}$ \\
\hline Plesiomonas sp. M6 & $\begin{array}{l}\text { Methyl parathion, } p \text { - } \\
\text { Nitrophenol }\end{array}$ & $\begin{array}{l}\text { Hydrolyze methyl parathion to } p \text {-nitrophenol and able to } \\
\text { use benzoic acid and phenylacetic acid as sole carbon } \\
\text { and energy source }\end{array}$ & Cui et al.,2001 \\
\hline Bacillus sp. & Parathion & $\begin{array}{l}\text { Hydrolyzed parathion to } p \text {-nitrophenol and liberated } \\
\text { nitrite from the hydrolysis product } p \text {-nitrophenol }\end{array}$ & $\begin{array}{l}\text { Siddaramappa et al., } \\
1973\end{array}$ \\
\hline $\begin{array}{l}\text { Pseudomonas sp. } \\
\text { WBC-3 }\end{array}$ & $\begin{array}{l}\text { Methyl parathion, } p \text { - } \\
\text { Nitrophenol }\end{array}$ & $\begin{array}{l}\text { Utilises methyl parathion (MP) or p-nitrophenol (PNP) as } \\
\text { the sole source of carbon, nitrogen, and energy }\end{array}$ & Liu et al., 2005 \\
\hline $\begin{array}{l}\text { Pseudomonas } \\
\text { aeruginosa MCMB-427 }\end{array}$ & Dimethoate & Degradation dimethoate with plasmid-mediated & $\begin{array}{l}\text { Deshpande et al., } \\
2001\end{array}$ \\
\hline Azospirillum & Ethion & Aerobic degradation of ethion in minimal salts medium & Foster et al., 2004 \\
\hline $\begin{array}{l}\text { Pseudomonas } \\
\text { aeruginosa HS-D38 }\end{array}$ & $\begin{array}{l}\text { Methyl parathion, } p \text { - } \\
\text { Nitrophenol }\end{array}$ & $\begin{array}{l}\text { degraded methyl parathion and } p \text {-nitrophenol as the sole } \\
\text { source of carbon, nitrogen and energy }\end{array}$ & Zheng et al., 2009 \\
\hline Pseudomonas putida & $\begin{array}{l}\text { Paraoxon, } \\
\text { Dimethoate, } \\
\text { Parathion }\end{array}$ & $\begin{array}{l}\text { Use as a sole carbon source, phosphorus source } \\
\text { and(or) energy source }\end{array}$ & $\begin{array}{l}\text { Mattozzi et al., 2003; } \\
\text { Nazarian, 2007; } \\
\text { Walker and Keasling, } \\
2002\end{array}$ \\
\hline Burkholderia sp. NF100 & Fenitrothion & $\begin{array}{l}\text { Used as a sole carbon source, hydrolyzed an } \\
\text { organophosphorus bond of fenitrothion, forming 3- } \\
\text { methyl-4-nitrophenol }\end{array}$ & Hayatsu et al., 2000 \\
\hline Micrococcus sp. & $\begin{array}{l}\text { Malathion, } \\
\text { Chlorpyriphos }\end{array}$ & $\begin{array}{l}\text { Degrade malathion and chlorpyriphos for growth as the } \\
\text { sole carbon source by plasmid-harboring strain } \\
\text { Utilize isoxathion as a sole nitrogen source and }\end{array}$ & Guha et al., 1997 \\
\hline Arthrobacter sp. B-5 & Isoxathion & $\begin{array}{l}\text { producted 3-hydroxy-5-phenylisoxazole and } \\
\text { diethylthiophosphoric acid } \\
\text { Degraded Dimethoate through cometobolism; }\end{array}$ & Ohshiro et al., 1999 \\
\hline Acinetobacter sp. & Dimethoate & $\begin{array}{l}\text { Dichlorvos, methamidophos and parathion can also be } \\
\text { degraded }\end{array}$ & Wang et al., 2001 \\
\hline Flavobacterium & Dichlorvos & $\begin{array}{l}\text { Utilize dichlorvos as the sole source of } \\
\text { phosphorus; Chlorpyrifos and phoxim could also be } \\
\text { degraded as the sole phosphorus source. } \\
\text { Biodegradation malathion under aerobic and energy- }\end{array}$ & Ning et al., 2012 \\
\hline Brevibacillus sp. KB2 & Malathion & $\begin{array}{l}\text { limiting conditions. The metabolites mal-monocarboxylic } \\
\text { acid and mal-dicarboxylic acid were identified }\end{array}$ & Singh et al., 2012 \\
\hline \multicolumn{4}{|c|}{ 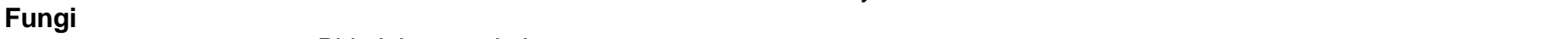 } \\
\hline Aspergillus flavus & $\begin{array}{l}\text { Plrimiphos-metnyl, } \\
\text { Pyrazophos, } \\
\text { Malathion }\end{array}$ & Used as phosphorus sources or carbon sources & Hasan, 1999 \\
\hline Trichoderma viride & Malathion & $\begin{array}{l}\text { Breakdown malathion through the action of a } \\
\text { carboxylesterase(s) }\end{array}$ & Matsumura, 1974 \\
\hline Penicillium waksmani & Parathion & $\begin{array}{l}\text { Tolerated parathion at concentrations as high as } 1000 \\
\text { ppm and converted it to aminoparathion }\end{array}$ & $\begin{array}{l}\text { Rao and Sethunathan, } \\
1974\end{array}$ \\
\hline $\begin{array}{l}\text { Penicillium lilacinum } \\
\text { BP303 }\end{array}$ & $\begin{array}{l}\text { Methyl parathion, } \\
\text { Parathion, Paraoxon }\end{array}$ & $\begin{array}{l}\text { Degrade various organophosphorus pesticides by } \\
\text { cleaving P-O in the phosphotriesters bond and P-S } \\
\text { linkage in the phosphothiolesters effectively }\end{array}$ & Liu et al., 2004 \\
\hline $\begin{array}{l}\text { Saccharomyces rouxii } \\
\text { WY-3 }\end{array}$ & Methamidophos & $\begin{array}{l}\text { Utilizing methamidophos as sole nitrogen and } \\
\text { phosphorus sources, and also capable of utilizing } \\
\text { methylamine, ethylamine and ammonium sulfate as } \\
\text { nitrogen sources except nitrate and hydroxylamine }\end{array}$ & Liu et al., 2001 \\
\hline \multicolumn{4}{|c|}{ - } \\
\hline Nocardia sp. & Coumaphos & $\begin{array}{l}\text { Coumaphos was used as a carbon source and } \\
\text { hydrolyzed to diethylthiophosphoric acid and chlorferon }\end{array}$ & Shelton, 1988 \\
\hline Microalgae & Methyl parathion & Utilized methyl parathion as a source of phosphorus & Megharaj et al., 1994 \\
\hline green algae & Fenamiphos & $\begin{array}{l}\text { Transformed fenamiphos to fenamiphos sulfoxide (FSO), } \\
\text { then to fenamiphos sulfoxide phenol (FSOP) }\end{array}$ & Cáceres et al., 2008 \\
\hline
\end{tabular}


Table 2. Characteristics of organophosphorus hydrolases isolated from microorganisms.

\begin{tabular}{lllccl}
\hline Name & $\begin{array}{l}\text { Accession } \\
\text { Number }\end{array}$ & Source & $\begin{array}{c}\text { Length } \\
(\mathbf{A A})\end{array}$ & $\begin{array}{c}\text { Mass } \\
(\approx \mathrm{kD})\end{array}$ & Reference \\
\hline OPD & AAV39527.1 & Flavobacterium sp. ATCC 27551 & 365 & 35 & Mulbry and Karns, 1989 \\
OPH & BAA85881.1 & Arthrobacter sp. & 415 & 44 & Ohshiro et al., 1999 \\
OPAA & AAB05590.1 & Alteromonas sp. & 517 & 60 & Cheng et al., 1996 \\
OPAB & AAA25371.1 & Mycobacterium sp. & 409 & 43 & Mulbry, 1992 \\
OPDA & AAK85308.1 & Agrobacterium radiobacte P230 & 384 & 41 & Horne et al., 2003 \\
OPDB & AAT67170.1 & Burkholderia sp. FDS-1 & 324 & 34 & Zhang et al., 2006 \\
MPDB & AAY18224.1 & Burkholderia cepacia & 331 & 35 & Ekkhunnatham et al., 2012 \\
OPHC2 & CAE53631.1 & Pseudomonas pseudoalcaligenes & 324 & 35 & Chu et al.., 2006 \\
MPH & AAP06948.1 & Pseudomonas sp. WBC-3 & 331 & 35 & Wei et al., 2009 \\
MPD & AAk14390.1 & Plesiomonas sp. M6 & 331 & 35 & Fu et al., 2004 \\
\hline
\end{tabular}

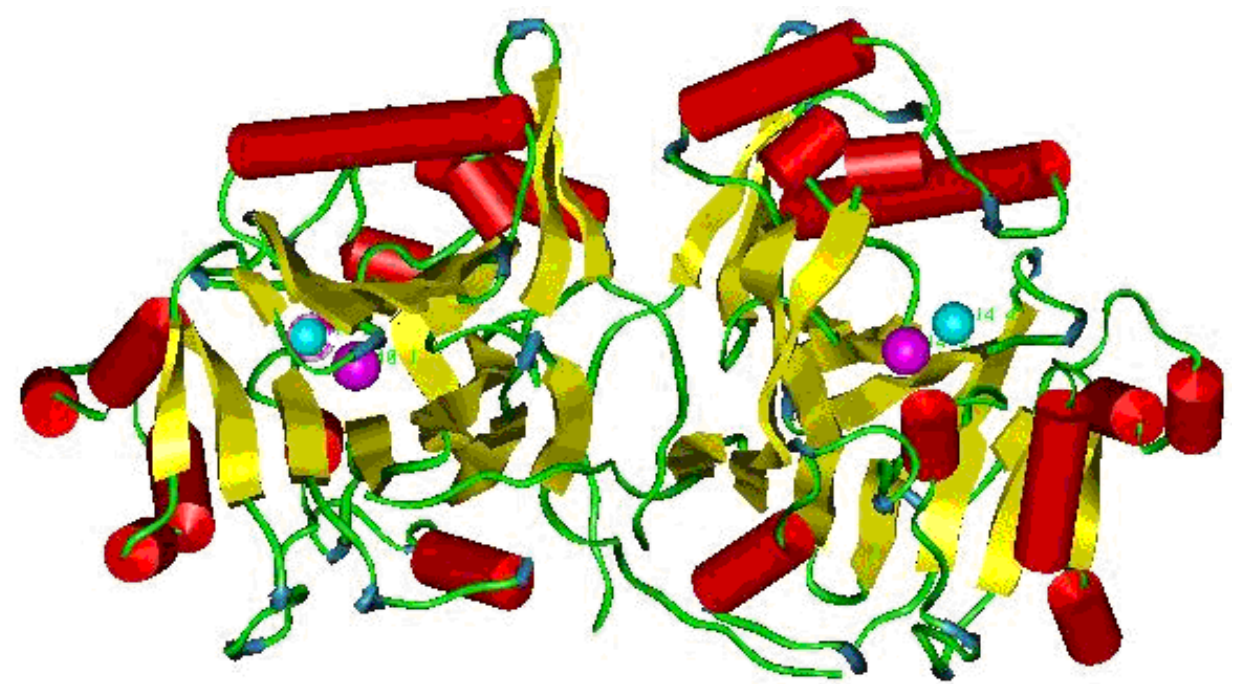

Figure 2. Representation of the $\mathrm{OPH}$ dimmer. A dimmer consist of two monomers. The mental binding active central consist of two metal ions (shown as pink and green spheres) (Zheng et al., 2008).

Vilanova, 2002; Kang et al., 2012), which had been isolated from both Flavobacterium sp. ATCC 27551 (Mulbry and Karns, 1989) and Pseudomonas diminuta MG (Phillips et al., 1990). Nowadays these unique enzymes have been isolated, purified and characterized, and has been demonstrated that these enzymes differ in high sensitivity to chemicals, substrate specificity, molecular mass and optimum reaction conditions (Table 2). Most of them were isolated from bacteria with little reports on organophosphorus compounds biotrans-formation by fungi. Liu et al. (2004) purified a novel fungal enzyme capable of hydrolyzing methyl parathion, parathion, paraoxon and coumaphos, and it degrades organophosphorus pesticides containing both $\mathrm{P}-\mathrm{O}$ bond and $\mathrm{P}-\mathrm{S}$ linkage effectively, which is the first broad-spectrum organophosphorus compound hydrolase iso-lated and purified from fungi.

\section{THREE-DIMENSIONAL STRUCTURET AND MUTATIONAL STUDIES OF OPH}

X-ray crystallographic studies and NMR spectroscopy analysis (Benning et al., 2001; Vanhooke et al.,1996) have verified that $\mathrm{OPH}$ is a dimeric metalloenzyme that contains two equivalents of zinc per monomer, which can be described as $\alpha \beta / \beta \alpha$ two-fold like metallo-hydrolase former (Figure 2). Two internal $\beta$-sheets are flanked each side by three $\alpha$-helices, a $\beta$-lactamase-like domain forms in the subunit domain, which includes the binuclear metal centre and several metals $\left(\mathrm{Co}^{2+}, \mathrm{Cd}^{2+}, \mathrm{Ni}^{2+}, \mathrm{Mn}^{2+}\right.$,or $\left.\mathrm{Fe}^{2+}\right)$ can substitute for the native zinc with varying affects on rates of hydrolysis (Zheng et al.,2008; Omburo et al.,1992). 
Different metal-associated form of the enzyme have demonstrated the varying hydrolytic capabilities for each of the OP neurotoxins, and the activity of $\mathrm{OPH}\left(\mathrm{Co}^{2+}\right)$ is consistently higher than that of $\mathrm{OPH}\left(\mathrm{Zn}^{2+}\right)$ by $5-$ to 20 folds (di Sioudi et al., 1999).

To increase the enzyme activity or enhance their broad-spectrum property, a variety of techniques have been used to evolve OPH enzyme. New active sites can be introduced into naturally occurring enzymes by the chemical modification of specific amino acid residues with the use of appropriately designed coenzyme analogs (Kaiser and Lawrence, 1984). Small-scale mutations such as point mutations, insertions and deletions were usually selected and operated (Grimsley et al., 2005). di Sioudi et al. (1999). have used the site-directed mutations of histidines near the native $\mathrm{OPH}$ active site and gained three $\mathrm{OPH}$ variants with a 4- to 30-fold increase in substrate specificity and enhanced rates of hydrolysis for demeton-S (P-S bond) and NPPMP (P-O bond), analogs for the chemical warfare agents $V X$ and soman, respectively. Another successful variant (H254R) in which the histidine at position 254 of $\mathrm{OPH}$ was changed to an arginine showed a 4-fold increase in the hydrolysis of demeton-S (VX analog) and a 14-fold decrease with paraoxon (Grimsley et al.,2005). Substitution of the histidine at position 254 of $\mathrm{OPH}$ enzyme could also affect the kinetic properties of substrates except paraoxon. The histidine at position 254 (His-254) is currently believed to assist the reaction by the shuttling of the proton from Asp-301 to the bulk solvent and away from the active site (Aubert et al.,2004). The opd gene was shuffled in search for enhanced variants for methyl parathion hydrolysis and the mutation $\mathrm{H} 257 \mathrm{Y}$ was found in all isolates that displayed higher activities (Cho et al., 2002). These researches clearly demonstrate that the active site of $\mathrm{OPH}$ can be manipulated for optimum decontamination and decomposition of the OPs and the $\mathrm{OPH}$ enzyme can be modified and direct evolution.

\section{POTENTIAL APPLICATIONS}

The traditional approaches (landfilling, recycling, pyrolysis and incineration) for the detoxification of organophosphorus compounds are harmful and possess serious environmental consequences. Therefore, utilizing functional strains or enzymes for the biodegradation and decontamination of organophosphorus agents has received considerable attention and it offers a promising strategy for economical and safe detoxification of OPs (Sogorb and Vilanova, 2002).

\section{Bioremediation}

Bioremediation is the use of microorganism metabolism to remove OPs pollutants, which is an eco-friendly, cost effective, highly efficient approach and can be considered as a superior, promising alternative to physical and chemical methods (Vermelho et al., 2012; Nawaz et al., 2011; Niu et al., 2011). The technologies can be generally classified as in situ or ex situ. In situ bioremediation is the process whereby OPs pollutants are biodegraded under natural conditions to either carbon dioxide and water or an attenuated transformation product. It is a low-cost, environment-friendly and sustainable approach for the cleanup of polluted sites, whereas the cost of ex situ bioremediation approaches can be high, relative to in situ methods (Ely et al., 2008). OPs in soil and water can be biodegraded by functional microorganisms and it is the primary mechanism of OPs breakdown, mineralization and detoxification in contamination soils (Surekha et al., 2008).

Mohan et al. (2004) applied the soil bioslurrysequencial batch reactors (SS-SBRs) for treating chlropyrifos contaminated soil under anoxic-aerobicanoxic condition. Rapid degradation of the substrate in soil matrix was observed in slurry phase system compared to the in situ decontaminate systems (it showed efficient performance in SBR that enforced short-term unsteady state conditions coupled with periodic exposure of the microorganisms to defined process conditions).

Pesticide-degrading epiphytic bacterium could also become a new way for in situ phyllosphere bioremediation where the hostile niche is unsuitable for other pesticide-degrading bacteria isolated from soil and water (Ning et al., 2012).

\section{Immobilization}

The immobilization of desired enzyme on suitable materials as carriers is currently gaining much attention in various fields of bioremediation. The enzyme immobilization has been recognized as a potential candidate for extending the process of organophosphorus compounds detoxification. In early research in immobilizing $\mathrm{OPH}$, a partially purified enzyme extract was covalently attached to porous glass and silica beads and were used in a continuous flow reactor to treat pesticide manufacturing wastewater. These studies indicate that the immobilized enzyme accomplished $95 \%$ hydrolysis of up to $250 \mathrm{ppm}$ parathion with no loss of activity after 70 days of continuous flow experiments (Munnecke, 1979). Pure OPH enzyme was first immobilized in trityl agarose in a fixed bed reactor. The immobilized enzyme was shown to behave chemically and kinetically similar to the free enzyme when paraoxon was utilized as a substrate. Several organophosphorus pesticides, methyl parathion, ethyl parathion, diazinon, and coumaphos were also hydrolyzed by the immobilized phosphotriesterase (Caldwell and Raushel, 1991). The insecticides paraoxon and parathion were successfully hydrolyzed by phosphotriesterase (PTE) that was immobilized on a trityl 
agarose matrix. The immobilization resulted in a relative increase in the stability of PTE and the maximum efficiency of the system was about $40 \%$ relative to the free enzyme (Wang et al., 2002; Ghanem and Raushel, 2005).

\section{Construction of genetically engineering bacteria}

With recent advances in biomolecular engineering, the bioremediation of organophosphorus compounds using genetically modified microorganisms has become a rapidly growing and promising fields of research for environmental protection. Two main biomolecular approaches, rational design and directed evolution, have been developed to engineer enhanced microorganisms and enzymes for the biodegradation of Ops (Ang et al., 2005). Lan et al. (2006) used a coexpression vector for the purpose of developing bacteria that can detoxify different pesticides. The vector $\mathrm{pETDuet}$ was designed for coexpression of two target genes simultaneously. The organophosphorus hydrolase gene (opd) from Flavobacterium sp. and carboxylesterase B1 gene (b1) from Culex pipiens were cloned in the coexpression vector. A genetically engineering bacterium was capable of producing both enzymes for degradation of organophosphorus, carbamate and pyrethroid pesticides. Zhang et al. (2004) constructed the recombinant insecticide-resistant mosquito carboxylesterase B1 to detoxify organophosphorous compounds. A combination of carboxylesterase B1 with the uncharged oxime diacetylmonoxime was used and demonstrated that the recombinant insecticide-resistant mosquito carboxylesterase with oxime is an effective approach for detoxification of organophosphorous compounds (Zhang et al., 2004). Another genetically engineered Escherichia coli cell expressing both organophosphorus hydrolase $(\mathrm{OPH})$ and a cellulose-binding domain (CBD) on the cell surface was constructed, enabling the simultaneous hydrolysis of organophosphorus nerve agents and immobilization via specific adsorption to cellulose. The immobilized cells degraded paraoxon rapidly at an initial rate of 0.65 $\mathrm{mM} / \mathrm{min} / \mathrm{g}$ of cells (dry weight) and retained almost $100 \%$ efficiency over a period of 45 days (Wang et al., 2002).

The specificity of native OPH has been further enhanced by alterations to the metal content of the enzyme as well as mutations to specific active site residues, which productively enhanced the ability of the enzyme to degrade specific OP compounds. di Sioudi et al. (1999) utilized a alternative expression systems to facilitate the native OPH protein aimed at the elucidation of cellular processing and secretion, and the optimization of purification protocols. OPH was chemically synthesized with a codon bias toward $E$. coli and followed by its cloning and heterologous over-expression in E. coli under induction with 0.1 M IPTG. The expressed enzyme was solubilised by mild treatment with incubation at $4^{\circ} \mathrm{C}$ to precipitate SDS. Results indicate that recombinant $\mathrm{OPH}$ was able to detoxify parathion and methyl parathion ranging between 10 to $80 \%$ and 3.6 to $45 \%$ in enzyme reaction cycles after immobilization on Ca-alginate and agaragar, respectively (Kapoor and Rajagopa, 2011). Khodi et al. (2012) used the recombinant $E$. coli display- ing organophosphorus hydrolase (OPH) to overcome the diffusion barrier limitation of organophosphorus pesticides, and the ability of recombinant $E$. coli that express significant activity to utilize diazinon as the sole source of energy without growth inhibition (Islam et al., 2010).

\section{CONCLUSIONS}

Organophosphorus compounds are most widely used in agriculture for crop production and other fields. The fate of organophosphorus compounds in the environment is associated with both abiotic and biotic processes, including volatization, photooxidation, chemical oxidation, bioaccumulation, and microbial transformation. Microorganisms are the predominant entities in the biosphere with an exceptional ability to degrade various OPs for their growth. Many functional microorganisms capable of degrading a special or several kinds of OPs have been isolated and characterized from different niches. They have evolved various novel degradation enzyme and pathway(s) for their metabolism. Organophosphorus hydrolase $(\mathrm{OPH})$ is a typical enzyme with the ability of hydrolyzing a wide variety of organophosphorus pesticides and chemical warfare agents. The organophosphorus pesticide hydrolase, including OPD, MPD, MPH, etc, belong to organophosphorus hydrolases family.

Organophosphorus hydrolase holds an intense interest and close attention should be paid by researcher for its higher enzyme activity and broad spectrum for the detoxification of OPs. The gene encoding OPH protein have been cloned and characterized from different functional strains, and was highly efficiently expressed not only in prokaryotic expression vector (Islam et al., 2010; Khodi et al., 2012) but also in eukaryocyte expression vector (Fukuda et al., 2010; Chu et al., 2006).

The specificity of native $\mathrm{OPH}$ has been further enhanced by alterations to the metal content of the enzyme as well as mutations to specific active site residues, which productively enhanced the ability of the enzyme to degrade specific OP compounds. To increase the enzyme activity or enhance their broad-spectrum property, native activated $\mathrm{OPH}$ was used to modify activated sites by the chemical modification of specific amino acid residues with the use of appropriately designed coenzyme analogs.

Functional strains and OPH enzyme have been applied extensively in the bioremediation of OPs pollutants. Bioremediation technologies can be generally classified as in situ or ex situ. In recent years, the immobilization of 
$\mathrm{OPH}$ enzyme on suitable materials as carriers is currently gaining much attention in various fields of bioremediation. Along with the development of the biochemistry and the molecular biology, and the other modem biological technology, such as genetic engineering, enzyme engineering, fermentation engineering and so on, many works have been carried out to change biology characteristic of $\mathrm{OPH}$, and to construct a versatile genetically engineering bacteria, which have creative and promising future in OPs detoxification.

\section{ACKNOWLEDGEMENTS}

This work was supported by the Key Grants of National Nature Science foundation of Hubei Province of China (2010CDA065), by the Key Grants of Educational Commission of Hubei Province of China (D20112902), by the Grant of Hubei Key Laboratory of Economic Forest Germplasm Improvement and Resources Comprehensive Utilization(2013000603); and by the Grant from the Ph.D. Programs Foundation of Huanggang Normal University of China (2011CD221).

\section{REFERENCES}

Allard A, Neilson AH (1997). Bioremediation of organic waste sites : A critical review of microbiological aspects. Environ. Res. 39:253-285.

Ang EL, Zhao H, Obbard JP (2005). Recent advances in the bioremediation of persistent organic pollutants via biomolecular engineering. Enzyme Microbial. Technol. 37:487-496.

Aubert SD, Li Y, Raushel FM (2004). Mechanism for the hydrolysis of organophosphates by the bacterial phosphotriesterase. Biochemistry 43:5707-5715.

Benning MM, Shim H, Raushel FM, Holden HM (2001). High resolution X-ray structures of different metal-substituted forms of phosphotriesterase from Pseudomonas diminuta. Biochemistry 40:27122722.

Bhushan B, Chauhan A, Samanta SK, Jain RK (2000). Kinetics of biodegradation of $p$-Nitrophenol by different bacteria. Biochem Biophys. Res. Commun. 630:626-630.

Cáceres TP, Megharaj M, Naidu R (2008). Biodegradation of the pesticide fenamiphos by ten different species of green algae and cyanobacteria. Curr. Microbiol. 57:643-646.

Caldwell SR, Raushel FM (1991). Detoxification of organophosphate pesticides using an immobilized phosphotriesterase from Pseudomonas diminuta. Biotechnol. Bioeng. 37:103-109.

Cheng TC, Harvey S P, Chen GL (1996). Cloning and expression of a gene encoding a bacterial enzyme for decontamination of organophosphorus nerve agents and nucleotide sequence of the enzyme. Appl. Environ. Microbiol. 62:1636-1641.

Cho CM, Mulchandani A, Chen W (2002). Bacterial cell surface display of organophosphorus hydrolase for selective screening of improved hydrolysis of organophosphate nerve agents. Appl. Environ. Microbiol. 68: 2026-2030.

Chu XY, Wu NF, Deng MJ, Tian J, Yao B, Fan YL (2006). Expression of organophosphorus hydrolase OPHC2 in Pichia pastoris: purification and characterization. Protein Expr Purif. 49:9-14.

Cui Z, Li S, Fang G (2001). Isolation of methyl parathion-degrading strain M6 and cloning of the methyl parathion hydrolase gene. Appl. Environ. Microbiol. 67:4922-4925.

Deshpande NM, Dhakephalkar PK, Kanekar PP (2001). Plasmidmediated dimethoate degradation Pseudomonas aeruginosa MCMB427. Lett. Appl. Microbiol. 33:275-279. di Sioudi B, Grimsley JK, Lai K, Wild JR (1999). Modification of near active site residues in organophosphorus hydrolase reduces metal stoichiometry and alters substrate specificity. Biochemistry 38:28662872.

Ekkhunnatham A, Jongsareejit B, Yamkunthong W, Wichitwechkarn J (2012). Purification and characterization of methyl parathion hydrolase from Burkholderia cepacia capable of degrading organophosphate insecticides. World J. Microbiol. Biotechnol. 28:1739-1746.

Ely F, Foo JL, Jackson CJ, Gahan L R, Ollis DL, Schenk G (2008). Enzymatic bioremediation: Organophosphate degradation by binuclear metallo-hydrolases. Current Topics Biochem. Res. 9:63-78.

Foster LJ, Kwan BH, Vancov T (2004). Microbial degradation of the organophosphate pesticide Ethion. FEMS Microbiol. Lett. 240:49-53.

Fu G, Cui Z, Huang T, Li S (2004). Expression, purification, and characterization of a novel methyl parathion hydrolase. Protein Expr Purif. 36:170-6.

Fukuda T, Tsuchiyama K, Makishima H, Takayama K, Mulchandani A, Kuroda K, Ueda M, Suye S (2010). Improvement in organophosphorus hydrolase activity of cell surface-engineered yeast strain using Flo1p anchor system. Biotechnol Lett. 32:655-659.

Gao Y, Chen S, Hu M, Hu Q, Luo J, Li Y (2012). Purification and characterization of a novel chlorpyrifos hydrolase from cladosporium cladosporioides Hu-01. PLoS One. 7,e38137.

Ghanem E, Raushel FM (2005). Detoxification of organophosphate nerve agents by bacterial phosphotriesterase. Toxicol. Appl. Pharmacol. 207:459-70.

Grimsley JK, Calamini B, Wild JR, Mesecar AD (2005). Structural and mutational studies of organophosphorus hydrolase reveal a cryptic and functional allosteric-binding site. Archives Biochem. Biophys. 442:169-79.

Guha A, Kumari B, Bora TC, Roy MK (1997). Possible involvement of plasmids in degradation of malathion and chlorpyriphos by Micrococcus sp. Folia Microbiol. 42:574-576.

Harper LL, Mcdaniel CS, Miller CE, Wild JR (2006). Dissimilar plasmids isolated from Pseudomonas diminuta $\mathrm{MG}$ and a Flavobacterium sp.(ATCC27551) contain identical opd genes. Appl. Environ. Microbiol. 54: 2586-2589.

Hasan HA (1999). Fungal utilization of organophosphate pesticides and their degradation by Aspergillus flavus and $A$. sydowii in soil. Folia Microbiol. (Praha). 44:77-84.

Hayatsu M, Hirano M, Tokuda S (2000). Involvement of two plasmids in fenitrothion degradation by burkholderia sp. Strain NF100. Appl. Environ. Microbiol. 66:1737-1740.

Hong F, Win KY, Pehkonen SO (2001). Hydrolysis of terbufos using simulated environmental conditions: rates, mechanisms, and product analysis. J. Agric. Food Chem. 49:5866-5873.

Horne I, Qiu X, Russell RJ, Oakeshott JG (2003). The phosphotriesterase gene opdA in Agrobacterium radiobacter P230 is transposable. FEMS Microbiol. Lett. 1:1-8.

Hsu YT, Su CY, Du HC, Jao SC, Li WS (2008). Evaluation of organophosphorus chemicals-degrading enzymes: a comparison of Escherichia coli and human cytosolic aminopeptidase. P. Chem. Biodivers .5:1401-11.

Islam SM, Math RK, Cho KM, Lim WJ, Hong SY, Kim JM, Yun MG, Cho JJ, Yun HD (2010). Organophosphorus hydrolase (OpdB) of Lactobacillus brevis WCP902 from kimchi is able to degrade organophosphorus pesticides. J. Agric. Food Chem. 58: 5380-5386.

Kaiser ET, Lawrence DS (1984). Chemical mutation of enzyme active sites. Science. 226:505-11.

Kang DG, Kim CS, Seo JH, Kim IG, Choi SS, Ha JH, Nam SW, Lim G, Cha HJ (2012). Coexpression of molecular chaperone enhances activity and export of organophosphorus hydrolase in Escherichia coli. Biotechnol. Prog, doi: 10.1002/btpr.1556.

Kapoor M, Rajagopa R (2011). Enzymatic bioremediation of organophosphorus insecticides by recombinant organophosphorous hydrolase. Int. Biodeter. Biodegrad. 65:896-901.

Kawahara K, Tanaka A, Yoon J, Yokota A (2010). Reclassification of a parathione-degrading Flavobacterium sp. ATCC 27551 as Sphingobium fuliginis, J Gen Appl Microbiol. 56: 249-55.

Khodi S, Latifi AM, Saadati M, Mirzaei M, Aghamollaei H (2012). Surface display of organophosphorus hydrolase on E. coli using N- 
terminal domain of ice nucleation protein InaV. J. Microbiol. Biotechnol. 22:234-238.

Lamoreaux R J, Newland L W (1977). The fate of organophosphorus pesticides in the environment. Biological Conservation. 11:59-66.

Lan WS, Gu JD, Zhang JL, Shen BC, Jiang H, Mulchandani A, Chen W, Qiao CL (2006). Coexpression of two detoxifying pesticide-degrading enzymes in a genetically engineered bacterium. Int. Biodeter. Biodegrad. 58:70-76.

Liu BB, Zhao YF, Chao YP, Xie YM,Wang YS (2001). Degradation of methamidophos by Saccharomyces rouxii WY-3. Environ. Sci. 22:3741.

Liu Y, Liu Y, Chen Z, Lian J, Huang X, Chung Y. (2004). Purification and characterization of a novel organophosphorus pesticide hydrolase from Penicillium lilacinum BP303. Enzyme and Microbial Technology. 34:297-303.

Liu H, Zhang J, Wang S, Zhang X, Zhou N (2005). Plasmid-borne catabolism of methyl parathion and p-nitrophenol in Pseudomonas sp. strain WBC-3. Biochem. Biophys. Res. Commun. 334:1107-1114.

Matsumura F (1974). Malathion degradation by Trichoderma viride and a Pseudomona sp. Science. 153:1278-1280.

Mattozzi MD, Tehara SK, Hong T, Keasling JD (2006). Mineralization of paraoxon and its use as a sole $C$ and $P$ source by a rationally designed catabolic pathway in Pseudomonas putida. Appl. Environ. Microbiol. 72:6699-6706.

Megharaj M, Madhavi DR, Screenivasulu C, Umamaheswari A (1994). Biodegradation of methyl-parathion by soil isolates of microalgae and cyanobacteria. Bull. Environ. Contam. Toxicol. 53:292-297

Mohan SV, Sirisha K, Rao NC, Sarma PN, Reddy SJ (2004). Degradation of chlorpyrifos contaminated soil by bioslurry reactor operated in sequencing batch mode: bioprocess monitoring. J. hazard. Mat. 116:39-48.

Mulbry WW, Karns JS (1989). Parathion hydrolase specified by the Flavobacterium opd gene: relationship between the gene and protein. J. Bacteriol. 171: 6740-6746.

Mulbry WW (1992). The aryldialkylphosphatase-encoding gene adpB from Nocardia sp. strain B-1: cloning, sequencing and expression in Escherichia coli. Gene. 121:149-153.

Munnecke DM (1979). Hydrolysis of organophosphate insecticides by an immobilized enzyme system. Biotechnol. Bioeng. 21:2247-2261.

Musa S, Gichuki JW, Raburu PO, Aura CM (2011). Risk assessment for organochlorines and organophosphates pesticide residues in water and sediments from lower Nyando/Sondu-Miriu river within Lake Victoria Basin, Kenya. Lakes \& Reservoirs. Res. Manage. 16: 273280.

Nawaz K, Hussain K, Choudary N, Majeed A, llyas UA, llyas U, Ghani A, Lin F, Ali K, Afghan F, Raza G,Lashari GI (2011). Eco-friendly role of biodegradation against agricultural pesticides hazards. Afr. J. Microbiol. Res. 5:177-183.

Nazarian A (2007). Utilization of dimethoate by wild type Pseudomonas putida from polluted sites in Iran. Pak. J. Biol. Sci. 10:664-667

Ning J, Gang G, Bai Z; Hu Q, Qi H, Ma A, Zhuan X, Zhuang G (2012). In situ enhanced bioremediation of dichlorvos by a phyllosphere Flavobacterium strain. Frontiers of Environmental Science and Engineering in China. 6:231-237

Niu M, Liu Z, Cui W, Li Z (2011). The bio-remediation technology of organophosphorus pesticides contaminated soil. Digital Manufacturing and Automation (ICDMA), 2011 Second International Conference.1217-1220

Ohshiro K, Kakuta T, Nikaidou N, Watanabe T, Uchiyama T (1999). Molecular cloning and nucleotide sequencing of organophosphorus insecticide hydrolase gene from Arthrobacter sp. strain B-5. J. Biosci. Bioeng. 87:531-534.

Omburo GA, Kuo JM, Mullins LS, Raushel FM (1992). Characterization of the zinc binding site of bacterial phosphotriesterase. J. Biol. Chem. 267:13278-13283.

Phillips JP, Xin JH, Kirby K, Milne Jr C P, Krell P, Wild JR (1990). Transfer and expression of an organophosphate insecticidedegrading gene

from Pseudomonas in Drosophila melanogaster. Proceedings of the National Academy of Sciences of the United States of America. 87:8155-8159.

Ragnarsdottir KV (2000). Enviromental fate and toxicology of organophosphate pesticides. J. Geol. Soc. 157:859-876.

Rao AV, Sethunathan N (1974). Degradation of parathion by Penicillium waksmani Zaleski isolated from flooded acid sulphate soil. Arch. Microbiol. 97:203-208.

Sethunathan N, Yoshida T (1973). A Flavobacterium $\mathrm{sp}$ that degrades diazinon and parathion. Can. J. Microbiol. 19: 873-875.

Shelton D (1988). Isolation and characterization of coumaphosmetabolizing bacteria from cattle dip. Appl. Environ. Microbiol. 54: 2566-2571.

Siddaramappa R, Rajaram KP, Sethuanthan N (1973). Degradation of parathion by bacteria isolated from flooded soil. Appl. Microbiol. 26:846-849.

Singh B, Kaur J, Singh K (2012). Biodegradation of malathion by Brevibacillus sp. strain KB2 and Bacillus cereus strain PU. World J. Microbiol. Biotechnol. 28:1133-1141.

Sogorb MA, Vilanova E (2002). Enzymes involved in the detoxification of organophosphorus, carbamate and pyrethroid insecticides through hydrolysis. Toxicol. Lett. 128:215-28.

Somara S, Manavathi B, Tebbe CC, Siddavatam D (2002). Localisation of identical organophosphorus pesticide degrading (opd)genes on genetically dissimilar indigenous plasmids of soil bacteria: PCR amplification, cloning and sequencing of opd gene from Flavobacterium balustinum. Indian JExp Biol. 40:774-779.

Surekha Rani M, Vijaya Lakshmi K, Suvarnalatha Devi P, Jaya Madhuri R, Aruna S, Jyothi K, Narasimha G, Venkateswarlu K (2008). Isolation and characterization of a chlorpyrifos degrading bacterium from agricultural soil and its growth response. Afr. J. Microbiol. Res. 2:26-31.

Timmis KN, Steffan RJ, Unterman R (1994). Designing microorganisms for the treatment of toxic wastes. Ann. Rev. Microbiol. 48:525-557.

Vanhooke JL, Benning MM, Raushel FM, Holden HM (1996). Threedimensional structure of the zinc-containing phosphotriesterase with the bound substrate analog diethyl 4-methylbenzylphosphonate. Biochemistry. 35:6020-6025.

Vermelho AB, Supuran CT, Guisan JM (2012). Microbial enzyme: applications in industry and in bioremediation. Enzyme Res, doi:10.1155/2012/980681

Walker AW, Keasling JD (2002). Metabolic engineering of Pseudomonas putida for the utilization of parathion as a carbon and energy source. Biotechnol. Bioeng. 78:715-721.

Wang YJ, Li SP, Shen B (2001). Isolation and activity of dimethoatedegrading strain. J. Nanjing Agric. Univ. 24:71-74.

Wang AA, Mulchandani A, Chen W (2002). Specific adhesion to cellulose and hydrolysis of organophosphate nerve agents by a genetically engineered Escherichia coli strain with a surfaceexpressed cellulose-binding domain and organophosphorus hydrolase. 68:1684-1689.

Wei M, Zhang JJ, Liu H, Wang SJ, Fu H, Zhou NY (2009). A transposable class I composite transposon carrying mph (methyl parathion hydrolase) from Pseudomonas sp. strain WBC-3. FEMS Microbiol. Lett. 292: 85-91.

Zhang JL, Qiao CL, Lan WS (2004). Detoxification of organophosphorus compounds by recombinant carboxylesterase from an insecticide-resistant mosquito and oxime-induced amplification of enzyme activity. Environ. Toxicol. 19:154-9.

Zhang Z, Hong Q, Xu J, Zhang X, Li S (2006). Isolation of fenitrothiondegrading strain Burkholderia sp. FDS-1 and cloning of mpd gene. Biodegradation 17:275-283.

Zheng Y, Liu D, Wang B, Zhang Q, Wan J, Li Xiong L, Li W (2008). Bioinformatics analysis of methyl parathion hydrolase MPH and the structure prediction with homology modeling. The 2nd International Conference on Bioinformatics and Biomedical Engineering. 1:13-16.

Zheng Y, Liu D, Xu H, Zhong Y, Yuan Y, Liu S, Xiao W (2009). Biodegradation of $\mathrm{p}$-nitrophenol by Pseudomonas aeruginosa HSD38 and analysis of metabolites with HPLC-ESI/MS. Int. Biodeter. Biodegrad. 63:1125-1129. 